\title{
Drug Resistance Process
}

National Cancer Institute

\section{Source}

National Cancer Institute. Drug Resistance Process. NCI Thesaurus. Code C16523.

Mechanisms, functions, activities, or processes exhibited by tumors or pathogens to withstand previously toxic drugs. 